\title{
Properties and Morphology of Polypropylene/Big Bags Compounds
}

\author{
Eduardo da Silva Barbosa Ferreira ${ }^{a} \star^{\oplus}$, Caio Henrique do Ó Pereira ${ }^{a}{ }^{\oplus}$, Edcleide Maria Araújo $^{a} \oplus^{\oplus}$ \\ Elieber Barros Bezerra ${ }^{\oplus}$, Danilo Diniz Siqueira ${ }^{a} \oplus$, Renate Maria Ramos Wellen ${ }^{b}($
}

\author{
${ }^{a}$ Departamento de Engenharia de Materiais, Universidade Federal de Campina Grande, Campina Grande, PB, Brasil \\ ${ }^{b}$ Departamento de Engenharia de Materiais, Universidade Federal da Paraíba, João Pessoa, PB, Brasil
}

Received: December 08, 2018; Revised: April 30, 2019; Accepted: June 23, 2019.

In this work, compounds based on two grades of polypropylene (PP), i.e., PP H503 or PP H103 with residues of Big bag fabrics $\left(\mathrm{R}_{\mathrm{BB}}\right)$ were processed in a corrotational twin screw extruder with $\mathrm{R}_{\mathrm{BB}}$ content ranging from $10 \%$ to $50 \%$ of the weight. Then, their thermal properties were investigated through Differential Scanning Calorimetry (DSC) and Thermogravimetry (TG); mechanical by tensile and impact; thermomechanic by heat deflection temperature (HDT); and their morphology by Scanning Electron Microscopy (SEM). With the aim to add maximum $\mathrm{R}_{\mathrm{BB}}$ content without considerable damage to the properties of neat PPs, it was observed that addition of $10 \%, 30 \%$ and $50 \%$ of $\mathrm{R}_{\mathrm{BB}}$ did not significantly interfere in the PP matrices, being the compound $\mathrm{PP}+30 \% \mathrm{R}_{\mathrm{BB}}$ which one presented more successful properties, leading to reused compounds with higher performance and lower costs at same time.

Keywords: Polypropylene, big bags, recycling.

\section{Introduction}

Currently due to the quick increase in the use of polymeric products, the Statista in 2016 shows the worldwide polypropylene (PP) production was 73.8 million tons, producing a large amount of post-consumer waste, and according to Sustainable Businesses only a small proportion of this plastic waste is recycled or reused, while a large amount of it is disposed in landfills causing serious environmental damage ${ }^{1,2}$. This serious scenario has worried the society and specifically the scientific community who has researched solutions for reusing and recycling these materials once they result in great problems mainly when improperly discarded in the environment and consequently, become a harmful material to the ecological system ${ }^{3,4}$. Consequently, there is an urgent requirement to develop "new products" made from residues i.e., with the insertion of post-consumer resins, in order to minimize the use of the virgin polymer, reducing costs and the disposal of materials ${ }^{5-9}$.

Among post-consumer products, there are big bags made with PP, which are used to pack several products in various sectors of the production chain as bagging seeds for warehouses, packaging fertilizers, bagging inputs, among other applications. Its main feature is strength and durability compared to other packaging. Polypropylene was introduced in the market in 1954, nowadays it is one of the most important thermoplastic, representing one of the bestselling in the world ${ }^{10-12}$.

Even with its wide applications, traditional polymeric resins, such as PP, have negative characteristics, such as their slow decomposition rate after disposal; along with low density the high consumption and the daily disposal end up generating high volumes of waste that accumulate for long periods, reducing the useful life of landfills ${ }^{13}$. There is an estimative that $80 \%$ of the solid waste from sanitary landfills in Brazil consists of thermoplastics, of which PP represents $10 \%{ }^{14,15}$.

The development of recycled plastic researches has allowed to discover quite surprising characteristics and innovations, associated to the advantages of material recovering, mostly processing polymer compounds. Researches carried out the production and application of polymer compounds based on PP and recycled materials ${ }^{13,16,17}$, presented good properties and the feasibility of PP recycling. However, although the subject is being explored, there is still a gap with works investigating uses of recycled PP from big bags in the development of new polymer compounds and products.

The aim of this work was to investigate compounds made with virgin $\mathrm{PP}$ upon addition of big bags $\left(\mathrm{R}_{\mathrm{BB}}\right)$ with contents ranging from $10 \%$ to $50 \%$ of the weight. These compounds were analyzed by thermal, mechanical, thermomechanical properties and the morphology, aiming to obtain the best content of $\mathrm{R}_{\mathrm{BB}}$ to be added in the developed compounds.

\section{Methodology}

\subsection{Materials}

Polypropylene $\mathrm{H} 103$ with density of $0.905 \mathrm{~g} / \mathrm{cm}^{3}$, MFR = $40 \mathrm{~g} / 10 \mathrm{~min}\left(230^{\circ} \mathrm{C} / 2.16 \mathrm{~kg}\right)$ and polypropylene $\mathrm{H} 503$ with density of $0.905 \mathrm{~g} / \mathrm{cm}^{3}, \mathrm{MFR}=3.5 \mathrm{~g} / 10 \mathrm{~min}\left(230^{\circ} \mathrm{C} / 2.16 \mathrm{~kg}\right)$, both manufactured by Braskem. Big bag residue $\left(\mathrm{R}_{\mathrm{BB}}\right)$, supplied by a company located in Campina Grande - PB.

*e-mail: eduardosbf95@gmail.com 


\subsection{Preparation of $R_{B B}$}

To obtain a suitable granulometry to be fed into the extruder, a master made from big bag fabrics was produced in a $\mathrm{MH}-$ Equipment $\mathrm{MH}-50 \mathrm{H}$ high-speed homogenizer using $25 \mathrm{~g}$ of material, which was homogenized for approximately 5 seconds (the camera temperature was checked being approximately $140^{\circ} \mathrm{C}$ ), afterwards the output from the homogenizer was freely cooled to room temperature $\left(\sim 23^{\circ} \mathrm{C}\right)$ and ground into a knife mill to obtain the granule shape.

\subsection{Extrusion of Compounds}

PP compounds were obtained using a modular interpenetrating corrotational twin screw extruder with $\mathrm{L} / \mathrm{D}$ ratio of 40 , model ZSK $18 \mathrm{~mm}$, Werner-Pfleiderer of Coperion, temperature profile used ranged between $185-195^{\circ} \mathrm{C}$, screw and feed rate were $250 \mathrm{rpm}$ and $4 \mathrm{~kg} / \mathrm{h}$, respectively. After extrusion the output was granulated and dried in a vacuum oven at $80{ }^{\circ} \mathrm{C}$ for 24 hours. The drying stage was executed to make sure no moisture would be present in the pellets, once after extrusion, the material goes through a cooling bath with circulating water, before being pelleted. Table 1 shows extruded compounds in weight ratios (\%).

Injected specimens for tensile, impact and HDT were produced according to ASTM D638, D256 (Type I) and D648, respectively, using an Arburg Injector, Model Allrounder 207C Golden Edition, operating at $180{ }^{\circ} \mathrm{C}$ in zone $1,190{ }^{\circ} \mathrm{C}$ in zones 2 and $3,210^{\circ} \mathrm{C}$ in zone 4 , the mold was kept at $20^{\circ} \mathrm{C}$.

Table 1. Compounds processed in this work.

\begin{tabular}{cccc}
\hline COMPOUNDS & PP H103 (\%) & PP H503 $(\%)$ & $\mathrm{R}_{\mathrm{BB}}(\%)$ \\
\hline PP H103 & 100 & - & - \\
PP H503 & - & 100 & - \\
PP H103/R & 90 & - & 10 \\
PP H103/R & 70 & - & 30 \\
PP H103/R & 50 & - & 50 \\
PP H503/R & - & 90 & 10 \\
PP H503/R & - & 70 & 30 \\
PP H503/R & - & 50 & 50 \\
\hline
\end{tabular}

\subsection{Characterizations}

To identify added fillings to $\mathrm{R}_{\mathrm{BB}}$, it was calcinated in a muffle (model EDG3P-S) from EDG Equipment. Approximately $58 \mathrm{~g}$ of material was heated from room temperature $\left(23^{\circ} \mathrm{C}\right)$ to $500^{\circ} \mathrm{C}$ at a heating rate of $5^{\circ} \mathrm{C} / \mathrm{min}$. The sample was kept at $500^{\circ} \mathrm{C}$ for 120 minutes afterwards the muffle was turned off and allowed to cool down to room temperature. The residual powder was weighted after 24 hours and analyzed by X-ray Fluorescence. It was also submitted to chemical analysis applying the semi quantitative method, under nitrogen atmosphere. From residual powder, pressed samples were produced with $10 \mathrm{~mm}$ diameter.
Thermogravimetry (TG) analyzes were performed in a TGA $51 \mathrm{H}$ Shimadzu, using $5 \pm 0.5 \mathrm{mg}$ of sample. The heating rate was $10^{\circ} \mathrm{C} / \mathrm{min}$, from room temperature $\left(23^{\circ} \mathrm{C}\right)$ to $500{ }^{\circ} \mathrm{C}$, under nitrogen atmosphere with gas flow rate of $100 \mathrm{~mL} / \mathrm{min}$.

Differential scanning calorimetry (DSC) analyzes were performed in a Shimadzu DSC-50, samples were heated from room temperature $\left(23^{\circ} \mathrm{C}\right)$ to $300^{\circ} \mathrm{C}$, and then cooled down to room temperature at a heating $/$ cooling rate of $10^{\circ} \mathrm{C} / \mathrm{min}$, under nitrogen atmosphere with gas flow rate of $50 \mathrm{~mL} / \mathrm{min}$.

The tensile tests carried out according to ASTM D 638, Elastic Modulus, Tensile Strength and Elongation were measured. The tests were performed in a universal EMIC model DL10000, using a load cell of $200 \mathrm{kgf}$, with deformation rate of $50 \mathrm{~mm} / \mathrm{min}$, operating at room temperature. Presented results are an average of 10 tests.

The IZOD impact strength tests were performed on notched specimens, using a Resil 5.5 from Ceast and a pendulum of $2.75 \mathrm{~J}$, according to ASTM D 256, at room temperature. Presented results are an average of 10 tests.

Heat deflection temperature (HDT) was obtained according to ASTM D 648, in a Ceast HDT 6 VICAT/N 6921.000, with a tension of $455 \mathrm{kPa}$, heating rate of $120{ }^{\circ} \mathrm{C} / \mathrm{h}(\operatorname{method} \mathrm{A})$. The temperature was determined after the sample having deflected $0.25 \mathrm{~mm}$. Presented results are an average of 3 tests.

Scanning electron microscopy (SEM) images were captured from injected fractured surface using a Tescan Veja 3 at a voltage of $30 \mathrm{kV}$ under high vacuum. Specimens were gold covered using a sputtering - Metallic Shimadzu - IC 50 , using a current of $4 \mathrm{~mA}$ for 2 minutes.

\section{Results and Discussion}

\subsection{Calcination and X-Ray Fluorescence - FRX}

From X-Ray Fluorescence and chemical analysis, the present oxides in PP compounds were identified as shown in Table 2. Calcium oxide $(\mathrm{CaO})$ was identified in the highest content, approximately $88 \%$, followed by titanium dioxide $\left(\mathrm{TiO}_{2}\right)$ with $4.1 \%$ and magnesium oxide $(\mathrm{MgO})$, around $3.7 \%$.

Table 2. Chemical analysis performed by X-ray fluorescence of $\mathrm{R}_{\mathrm{BB}}$

\begin{tabular}{cc}
\hline OXIDES & CONTENT $(\%)$ \\
\hline $\mathrm{CaO}$ & 87.81 \\
$\mathrm{TiO}_{2}$ & 4.13 \\
$\mathrm{MgO}$ & 3.69 \\
$\mathrm{SiO}_{2}$ & 1.15 \\
$\mathrm{ZnO}$ & 1.06 \\
$\mathrm{SO}_{3}$ & 0.93 \\
$\mathrm{Al}_{2} \mathrm{O}_{3}$ & 0.83 \\
$\mathrm{~K}_{2} \mathrm{O}$ & 0.28 \\
$\mathrm{SrO}$ & 0.06 \\
$\mathrm{CuO}$ & 0.04 \\
$\mathrm{ZrO}_{2}$ & 0.02 \\
\hline
\end{tabular}


These three oxides represent more than $95 \%$ of the mineral fillers added to virgin PP during big bags processing to obtain the fabrics of big bags. These additives may act as pigments providing white color $(\mathrm{CaO})$, ultraviolet resistance (anti-uv) $\left(\mathrm{TiO}_{2}\right)$, nucleation, among other properties, probably they behave as external agents during recycling of $\mathrm{R}_{\mathrm{BB}}$ implying in changes in virgin $\mathrm{PP}^{18-19}$.

\subsection{Thermogravimetry (TG)}

The thermal stability of PP H103, PP H503, $\mathrm{R}_{\mathrm{BB}}$, and its compounds was investigated by TG, Figures 1 and 2 display TG plots.

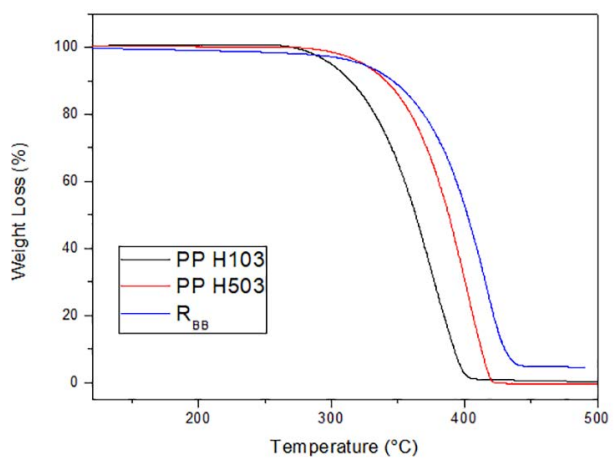

Figure 1. TG curves of PP H103, PP H503 and $\mathrm{R}_{\mathrm{BB}}$.

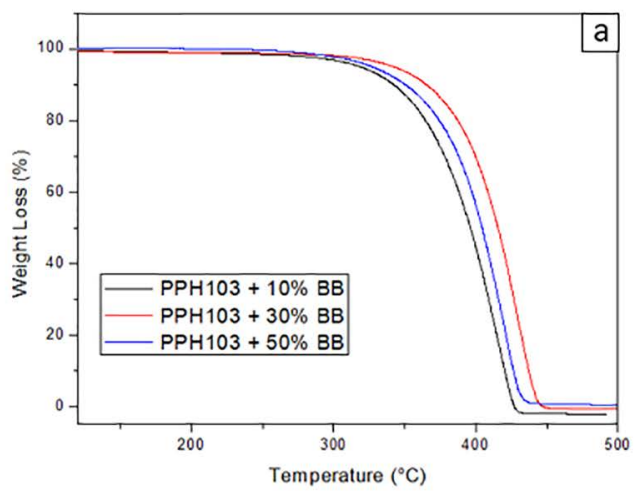

From TG plots in Figure 1 is verified that PP H103, PP $\mathrm{H} 503$ and $\mathrm{R}_{\mathrm{BB}}$ have distinct characteristics. Decomposition temperatures are possibly associated to the difference in the viscosity between PPs, where PP H503 being more viscous has a higher molecular weight and consequently greater macromolecular entanglements, leading to a higher energy consumption to break the chains, therefore to higher degradation/decomposition temperatures as already observed by Rjeb et al. $(2005)^{20}$. The plot for $\mathrm{R}_{\mathrm{BB}}$ displays weight loss in higher temperature than those observed for PP H103 and PP H503 what can be attributed to the mineral fillers/ additives as evidenced by FRX analysis ${ }^{18-19}$.

Figure 2 presents TG plots of PP compounds with 10, 30 and $50 \%$ of $\mathrm{R}_{\mathrm{BB}}$. It can be verified that upon addition of $30 \%$ $\mathrm{R}_{\mathrm{BB}}$ the thermal stability of both PPs significantly increased, it was even higher than those observed for compounds with $50 \% \mathrm{R}_{\mathrm{BB}}$, probably resulted due to an overhead effect of the added mineral fillers ${ }^{18-19}$.

\subsection{Differential Scanning Calorimetry (DSC)}

Figure 3 presents DSC scans of PP H103, PP H503 and $\mathrm{R}_{\mathrm{BB}}$, from these scans, melting and crystallization temperatures $\left(\mathrm{T}_{\mathrm{m}}\right.$ and $\left.\mathrm{T}_{\mathrm{c}}\right)$, melting and crystallization enthalpies $\left(\Delta \mathrm{H}_{\mathrm{m}}\right.$ and $\left.\Delta \mathrm{H}_{\mathrm{c}}\right)$, and degree of crystallinity $\left(\mathrm{X}_{\mathrm{c}}\right)$ were evaluated and are presented in Table 3 .

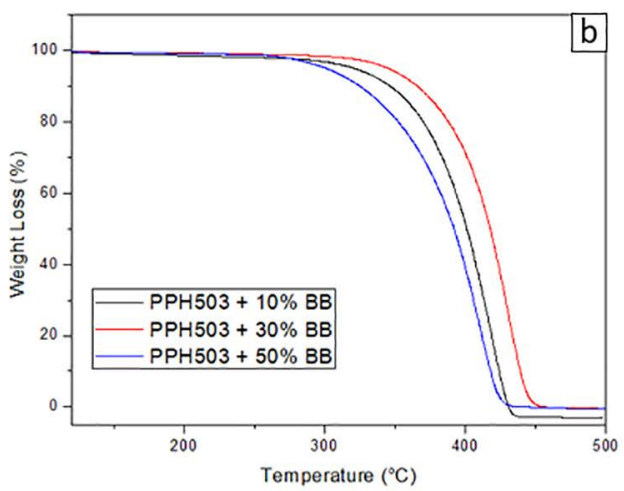

Figure 2. TG curves of PP H103 (a) and PP H503 (b) compounds with 10, 30 and 50\% of $\mathrm{R}_{\mathrm{BB}}$.
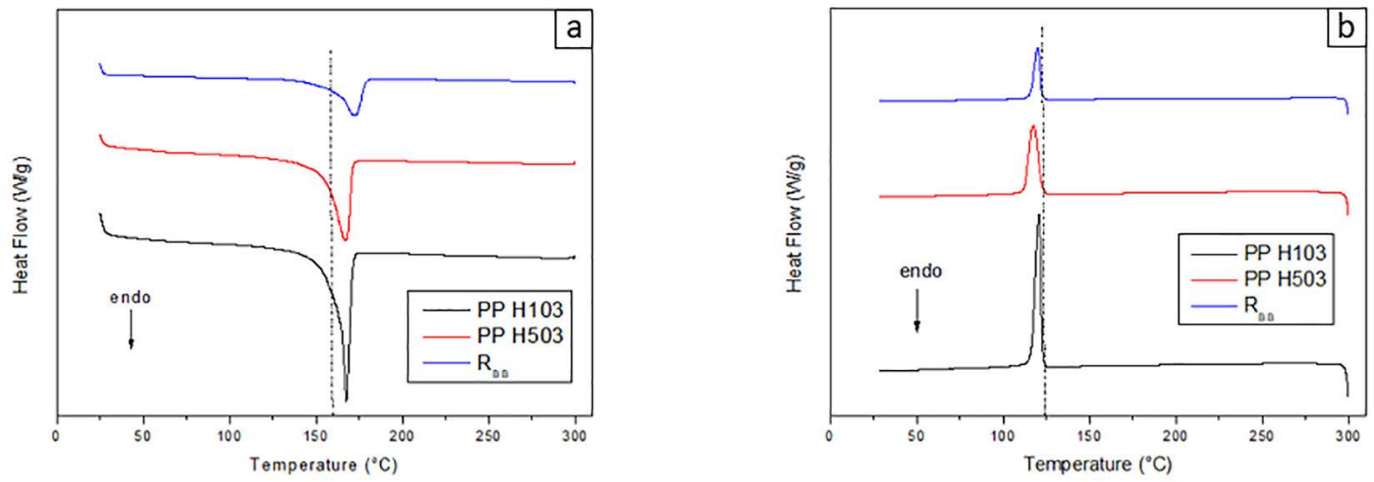

Figure 3. DSC curves of PP H103, PP H503 and $\mathrm{R}_{\mathrm{BB}}$ acquired during heating (a) and cooling (b) at $10^{\circ} \mathrm{C} / \mathrm{min}$. 
Melting endotherms related to fusion of crystals are observed during heating, in Figure 3a. The melting peak of $\mathrm{R}_{\mathrm{BB}}$ is displayed at relatively higher temperatures, possibly due to the formation of larger and/or more stable crystals due to the stretching during processing leading to a greater orientation or even due to the presence of mineral fillers as evidenced in Table $2^{12,18,19}$.

Regarding the exotherms of melt crystallization, Figure $3 \mathrm{~b}$ PPs and $\mathrm{R}_{\mathrm{BB}}$ presented single peaks with bell shape translating as crystallization without discontinuities. PP H503 presented $\mathrm{T}_{\mathrm{c}}$ in $117^{\circ} \mathrm{C}$ slightly lower than PP H103 $\left(120^{\circ} \mathrm{C}\right)$ and $\mathrm{R}_{\mathrm{BB}}$ $\left(120^{\circ} \mathrm{C}\right)$, most likely due to the higher viscosity leading to an entanglement state lowering the macromolecular packaging, as was also verified during melting.

PP $\mathrm{H} 103$ and $\mathrm{R}_{\mathrm{BB}}$ have higher $\mathrm{T}_{\mathrm{c}}$, which may be associated to smaller polymer chains. PP H103 has higher MFR (40 g/10 min), this fact may improve crystallization (nucleation and growth), as already reported by Oliveira et al. (2012) ${ }^{21}$. In addition, the presence of impurities can contribute to a higher crystallization rates, they may act as activation centers for new crystals ${ }^{22}$.
Concerning the degree of crystallinity as shown in Table 3 samples presented close values, being PP H503 subtly less crystalline, probably due to higher molecular weight, making difficult the macromolecular packaging and thus the crystallization.

Figures 4 and 5 present DSC scans for PP compounds with $10 \%, 30 \%$ and $50 \%$ of $\mathrm{R}_{\mathrm{BB}}$. Both crystallization and melting are displayed as bell shape, taking place as processes without discontinuities. Interesting characteristic is verified where even upon addition of $50 \%$ of $\mathrm{R}_{\mathrm{BB}}$ the thermal properties are preserved. In Table 3 , thermal parameters are presented, evidencing similar data between neat and compounded PP.

\subsection{Mechanical Properties}

Mechanical properties of neat PP H103 and PP H503 and their compounds with $\mathrm{R}_{\mathrm{BB}}$ in contents of $10 \%, 30 \%$ and $50 \%$ are presented in Table 4 . Related to Elastic Modulus data observed for PP H103 it is higher than for P H503 providing higher stiffness and lower flexibility ${ }^{24,25}$. Upon addition of $\mathrm{R}_{\mathrm{BB}}$, compounds presented Elastic Modulus between $10 \%$ and $20 \%$ higher than neat PPs, presence of mineral fillers as the main contribution for this.

Table 3. Melting and crystallinity parameters of PP H103, PP H503 and $\mathrm{R}_{\mathrm{BB}}$.

\begin{tabular}{|c|c|c|c|c|c|}
\hline \multirow{2}{*}{ COMPOUNDS } & \multicolumn{3}{|c|}{ MELTING } & \multicolumn{2}{|c|}{ MELT CRYSTALLIZATION } \\
\hline & $\mathrm{T}_{\mathrm{m}}\left({ }^{\circ} \mathrm{C}\right)$ & $X_{c}(\%)$ & $\Delta \mathrm{H}_{\mathrm{m}}(\mathrm{J} / \mathrm{g})$ & $\mathrm{T}_{\mathrm{c}}\left({ }^{\circ} \mathrm{C}\right)$ & $\Delta \mathrm{H}_{\mathrm{c}}(\mathrm{J} / \mathrm{g})$ \\
\hline PP H103 & 167 & 57 & 78.58 & 120 & 101.07 \\
\hline PP H503 & 166 & 63 & 87.42 & 117 & 100.6 \\
\hline $\mathrm{R}_{\mathrm{BB}}$ & 173 & 35 & 45.24 & 120 & 44.99 \\
\hline $\mathrm{PP} \mathrm{H} 103+10 \% \mathrm{R}_{\mathrm{BB}}$ & 166 & 60 & 82.64 & 120 & 102.4 \\
\hline $\mathrm{PP} \mathrm{H} 103+30 \% \mathrm{R}_{\mathrm{BB}}$ & 167 & 57 & 79.09 & 118 & 97.9 \\
\hline $\mathrm{PP} \mathrm{H} 103+50 \% \mathrm{R}_{\mathrm{BB}}$ & 165 & 54 & 74.65 & 117 & 94.21 \\
\hline PP $\mathrm{H} 503+10 \% \mathrm{R}_{\mathrm{BB}}$ & 166 & 68 & 94.39 & 117 & 107.7 \\
\hline PP H503 + 30\% $\mathrm{R}_{\mathrm{BB}}$ & 165 & 61 & 84.28 & 118 & 101.5 \\
\hline PP H503 + 50\% $\mathrm{R}_{\mathrm{BB}}$ & 166 & 56 & 77.49 & 117 & 96.51 \\
\hline
\end{tabular}

$\mathrm{T}_{\mathrm{m}}=$ melting peak temperature; $\Delta \mathrm{H}_{\mathrm{m}}=$ melting enthalpy; $\mathrm{X}_{\mathrm{c}}=$ degree of crystallinity, measured as $\mathrm{X}_{\mathrm{c}}=\Delta \mathrm{H}_{\mathrm{m}} / \Delta \mathrm{m}^{\circ} ; \mathrm{T}_{\mathrm{c}}=$ Crystallization peak temperature; $\Delta \mathrm{H}_{\mathrm{c}}=$ crystallization enthalpy; $\Delta \mathrm{Hm}^{\circ}=$ equilibrium melting enthalpy assuming PP crystal $100 \%$ crystalline, $138 \mathrm{~J} / \mathrm{g}$. Libano et al. $(2011)^{23}$.

Table 4. Mechanical properties of PP H103, PP H503 and PP/ $\mathrm{R}_{\mathrm{BB}}$ systems.

\begin{tabular}{|c|c|c|c|}
\hline COMPOUNDS & ELASTIC MODULUS (MPa) & TENSILE STRENGTH (MPa) & IMPACT STRENGTH $(\mathrm{J} / \mathrm{m})$ \\
\hline PP H103 & $602.6 \pm 17.8$ & $33.2 \pm 0.6$ & $21.64 \pm 1.3$ \\
\hline PP H503 & $578.4 \pm 10.7$ & $34.5 \pm 0.2$ & $31.29 \pm 2.5$ \\
\hline PP H103 + 10\% $\mathrm{R}_{\text {вв }}$ & $610.3 \pm 3.5$ & $33.2 \pm 0.4$ & $21.97 \pm 1.3$ \\
\hline $\mathrm{PP} \mathrm{H} 103+30 \% \mathrm{R}_{\mathrm{BB}}$ & $681.0 \pm 6.1$ & $33.2 \pm 0.3$ & $24.21 \pm 2.8$ \\
\hline PP H103 + 50\% $\mathrm{R}_{\text {Bв }}$ & $659.8 \pm 7.6$ & $33.1 \pm 0.2$ & $23.08 \pm 3.3$ \\
\hline PP $\mathrm{H} 503+10 \% \mathrm{R}_{\mathrm{BB}}$ & $691.7 \pm 11.4$ & $33.3 \pm 0.4$ & $32.24 \pm 1.4$ \\
\hline PP H503 + 30\% R & $648.9 \pm 31.0$ & $32.9 \pm 0.5$ & $31.69 \pm 2.9$ \\
\hline $\mathrm{PP} \mathrm{H} 503+50 \% \mathrm{R}_{\mathrm{BB}}$ & $677.5 \pm 18.4$ & $33.0 \pm 0.5$ & $29.98 \pm 2.3$ \\
\hline
\end{tabular}



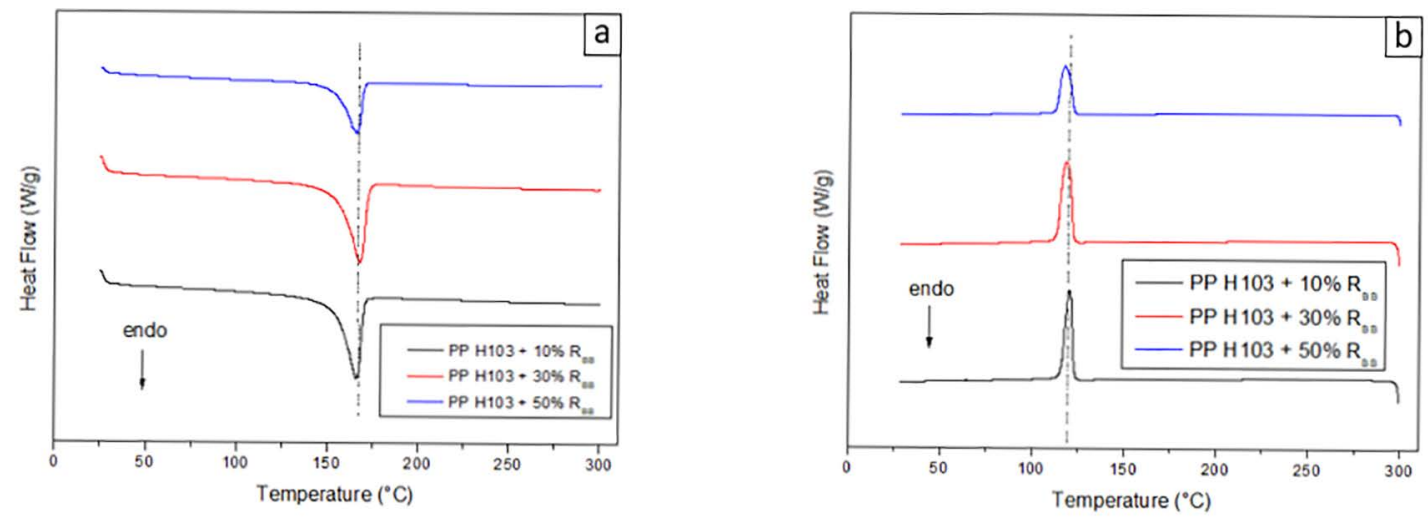

Figure 4. DSC curves of PP H103 compounds acquired during heating (a) and cooling (b) at $10^{\circ} \mathrm{C} / \mathrm{min}$.
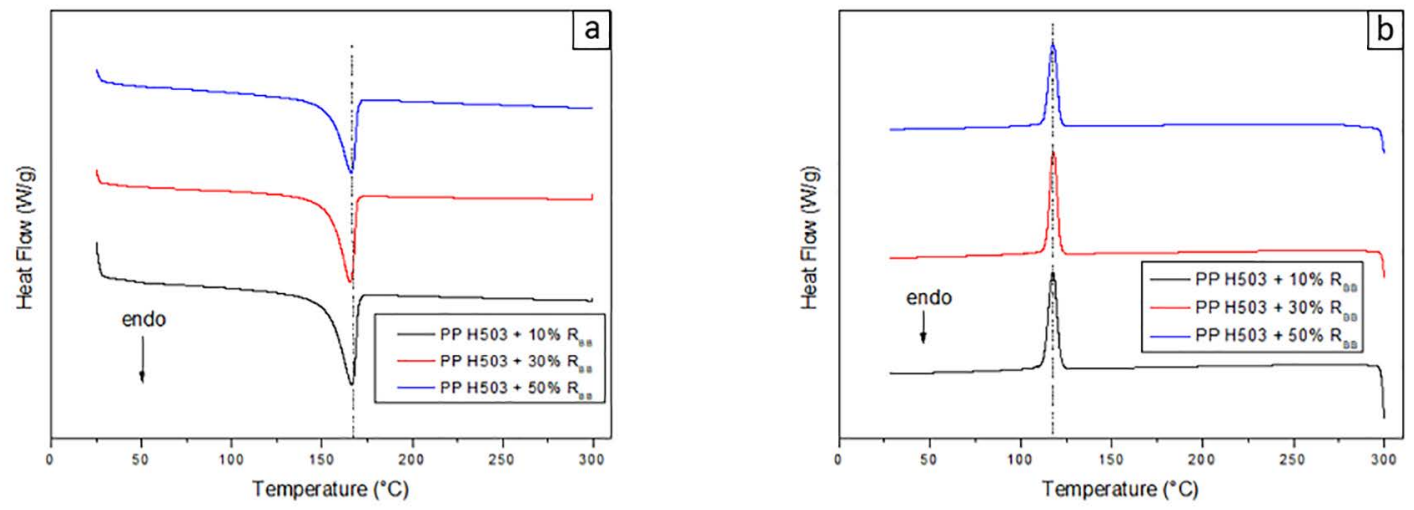

Figure 5. DSC curves of PP H503 compounds acquired during heating (a) and cooling (b) at $10^{\circ} \mathrm{C} / \mathrm{min}$.

Regarding Tensile Strength, investigated compounds display similar values, while PP H503 presented higher Impact Strength, on average data were $30 \%$ higher than compounds with PP H103. In general, addition of $\mathrm{R}_{\mathrm{BB}}$ leaded to an improvement of impact, possibly mineral fillers provide better energy absorption ${ }^{18,19,11}$. The results obtained with tensile and impact experiments give evidence that addition of $\mathrm{R}_{\mathrm{BB}}$ to neat $\mathrm{PP}$ provide compounds with higher performance at lower cost.

\subsection{Heat Deflection Temperature (HDT)}

In order to evaluate the thermomechanical behavior of PP H103 and PP H503 their compounds with 10\%, 30\% and $50 \%$ of $\mathrm{R}_{\mathrm{BB}}$, were submitted to HDT test and data are shown in Table 5. For PP H103, it can be observed, despite addition of $\mathrm{R}_{\mathrm{BB}}$, HDT data kept invariable, at approximately $93{ }^{\circ} \mathrm{C}$.

For PP H503, compounds with $\mathrm{R}_{\mathrm{BB}}$ presented higher HDT, being the highest PP $\mathrm{H} 503+30 \% \mathrm{R}_{\mathrm{BB}}$, this increase may be associated to an increase in the Elastic Modulus as above observed leading to higher energy requirement to change shape, what can be translated in materials with longer life cycles and better performance.
Table 5. HDT of PP H103, PP H503 and PP/ $R_{B B}$ compounds.

\begin{tabular}{lc}
\hline COMPOUNDS & HDT $\left({ }^{\circ} \mathrm{C}\right)$ \\
\hline PP H103 & $93.37 \pm 1.1$ \\
PP H503 & $89.87 \pm 0.5$ \\
PP H103 + 10\% $\mathrm{R}_{\mathrm{BB}}$ & $93.37 \pm 0.7$ \\
PP H103 + 30\% $\mathrm{R}_{\mathrm{BB}}$ & $93.80 \pm 1.7$ \\
PP H103 + 50\% $\mathrm{R}_{\mathrm{BB}}$ & $93.63 \pm 1.3$ \\
PP H503 + 10\% $\mathrm{R}_{\mathrm{BB}}$ & $95.70 \pm 1.1$ \\
PP H503 + 30\% $\mathrm{R}_{\mathrm{BB}}$ & $98.63 \pm 1.7$ \\
${\text { PP H503 }+50 \% \mathrm{R}_{\mathrm{BB}}}$ & $97.23 \pm 0.1$ \\
\hline
\end{tabular}

According to McCaffrey et al. (2018) ${ }^{26}$, HDT is the temperature in which a pronounced decrease in mechanical properties is verified, i.e., higher HDT greater thermal resistance. Therefore, as above presented $\mathrm{R}_{\mathrm{BB}}$ leaded to better thermal resistance.

\subsection{Scanning Electron Microscopy (SEM)}

Figures 6 and 7 present SEM images of PP H103 and PP $\mathrm{H} 503$, and compounds with $10 \%, 30 \%$ and $50 \%$ of $\mathrm{R}_{\mathrm{BB}}$. Disperse $\mathrm{R}_{\mathrm{BB}}$ aggregates are observed in PP matrices, however segregation is absent, what could conduct to lower mechanical performance. 

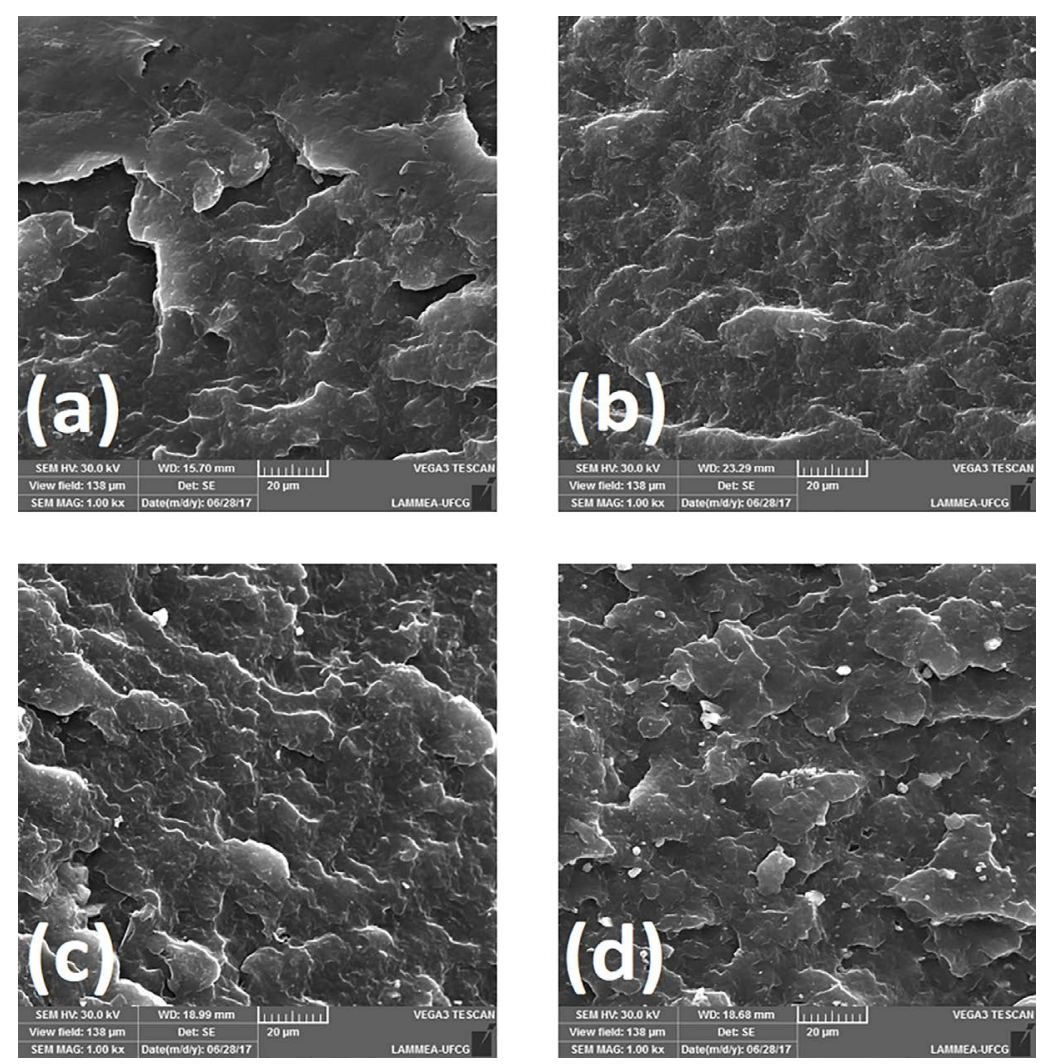

Figure 6. SEM images of (a) PP H103, (b) PP H103 + $10 \% \mathrm{R}_{\mathrm{BB}}$, (c) PP H103+30\% $\mathrm{R}_{\mathrm{BB}}$ and (d) $\mathrm{PP} \mathrm{H} 103+50 \% \mathrm{R}_{\mathrm{BB}}$.
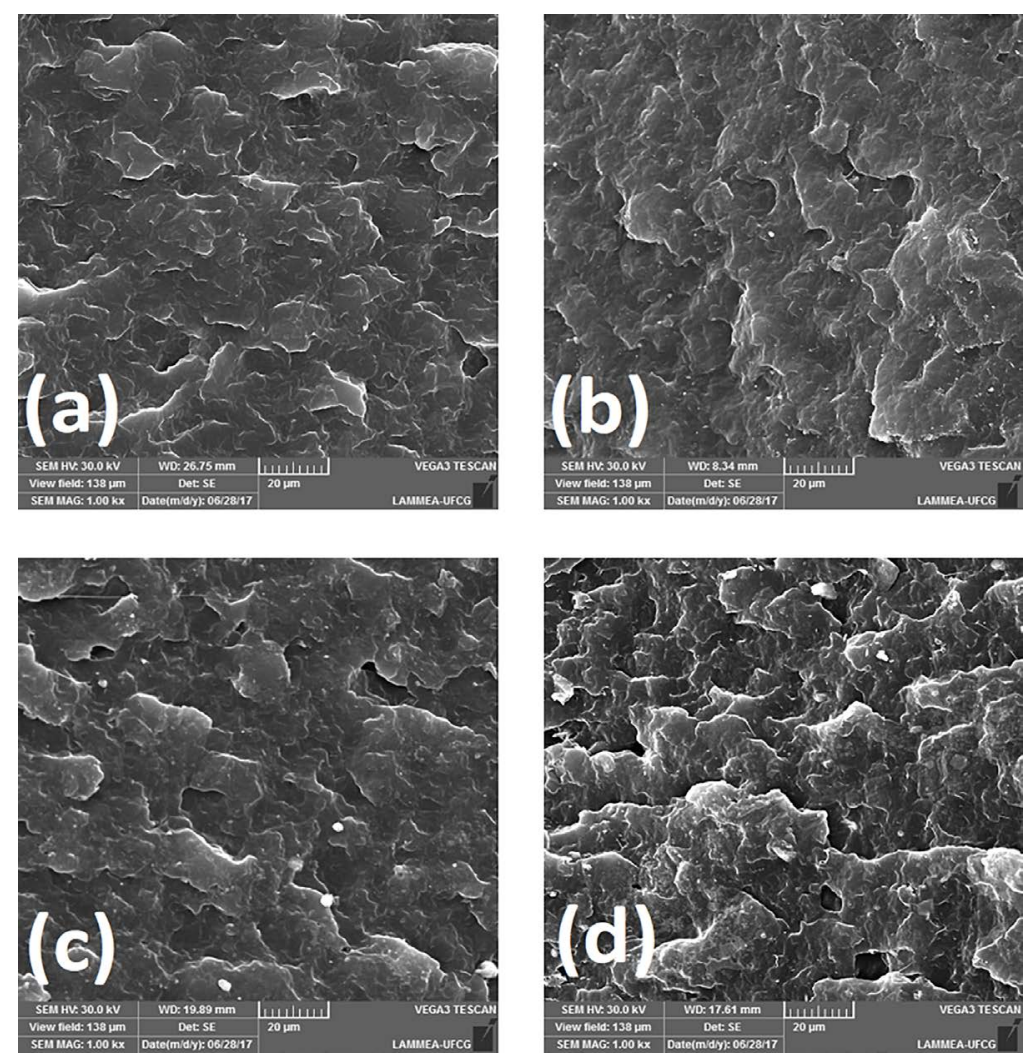

Figure 7. SEM images of (a) PP H503, (b) PP $\mathrm{H} 503+10 \% \mathrm{R}_{\mathrm{BB}}$, (c) PP H503 $+30 \% \mathrm{R}_{\mathrm{BB}}$ and (d) $\mathrm{PP} \mathrm{H} 503+50 \% \mathrm{R}_{\mathrm{BB}}$. 
According to these images is verified both neat PPs and compounds presented ductile fracture with rough fracture surfaces and energy absorption mechanisms working properly agreeing with Impact Strength analyses behavior.

\section{Conclusions}

Polypropylene compounds with big bag residue $\left(\mathrm{R}_{\mathrm{BB}}\right)$ were melt extruded, afterwards their thermal, mechanical; thermomechanical and morphological properties were investigated. From the results, it was verified $\mathrm{R}_{\mathrm{BB}}$ recycling is economically viable, saving raw material, i.e., neat $\mathrm{PP}$ and energy. PPs morphological character was kept after adding $\mathrm{R}_{\mathrm{BB}}$ in contents up to $50 \%$ of the weight and higher thermal stability was observed in the compounds. There was also an increase in the Elastic Modulus with no significant change in tensile and impact strengths. Summing up, compounds with $30 \%$ of $\mathrm{R}_{\mathrm{BB}}$ present satisfactory properties and are economically viable, and can be used for sealing caps; toys; food packaging for food and cosmetics, products for general use, electronic devices.

\section{Acknowledgement}

The authors thank Labmat (Laboratory of Materials Engineering/CCT/UFCG) for tensile, impact strength, thermogravimetry and differential scanning calorimetry experiments, CNPq, MCTIC/CNPq and CAPES/PNPD for the financial support.

\section{References}

1. Leblanc R. An Overview of Polypropylene Recycling. New York: Sustainable Business; 2018. Available from: <https:// www.thebalancesmb.com/an-overview-of-polypropylenerecycling-2877863>. Access in: 26/04/2019.

2. Statista. Production of polypropylene worldwide in 2016 by region (in million tons). New York: Statista: The Statistics Portal; 2018. Available from: <https://www.statista.com/ statistics/732167/distribution-of-polypropylene-consumptionworldwide-by-region/>. Access in: 26/04/2019.

3. de Faria PC, Wisbeck E, Dias LP. Biodegradação de polipropileno reciclado (ppr) e de poli (tereftalado de etileno) reciclado (petr) por Pleurotus ostreatus. Matéria (Rio de Janeiro). 2015;20(2):452-459.

4. França DC, Morais DD, Bezerra EB, Araújo EM, Wellen RMR. Photodegradation Mechanisms on Poly ( $\varepsilon$-caprolactone)(PCL). Materials Research. 2018;21(5):e20170837.

5. Nunes SG, da Silva LV, Amico SC, Viana JD, Amado FDR. Study of Composites Produced with Recovered Polypropylene and Piassava Fiber. Materials Research. 2017;20(1):144-150.

6. Forlin FJ, Faria JAF. Considerações Sobre a Reciclagem de Embalagens Plásticas. Polímeros. 2002;12(1):1-10.
7. Battistelle R, Viola NM, Bezerra BS, Vilarelli ID. Caracterização física e mecânica de um compósito de polipropileno reciclado e farinha de madeira sem aditivos. Matéria (Rio de Janeiro). 2014;19(1):7-15.

8. Ignatyev IA, Thielemans W, Beke B. Recycling of polymers: A review. ChemSusChem. 2014;7(6):1579-1593.

9. Araújo LMG, Morales AR. Compatibilization of recycled polypropylene and recycled poly (ethylene terephthalate) blends with SEBS-g-MA. Polimeros. 2018;28(1):84-91.

10. Martins AF, Suarez JCM, Mano EB. Produtos poliolefínicos reciclados com desempenho superior aos materiais virgens correspondentes. Polímeros. 1999;9(4):27-32.

11. Machado JCV. Reologia e Escoamento de Fluidos: Ênfase na Indústria de Petróleo. Rio de Janeiro: Editora Interciencia; 2002.

12. Holzschuh GG. Controle de Qualidade na Indústria de Ráfia Padronização e Otimização dos Processos. [Dissertation]. Santa Cruz do Sul: University of Santa Cruz do Sul; 2009.

13. Fernandes BL, Domingues AJ. Caracterização mecânica de polipropileno reciclado para a indústria automotiva. Polímeros. 2007;17(2):85-87.

14. Rodrigues A, Carvalho BM, Pinheiro LA, Bretas RES, Canevarolo SV, Marini J. Effect of compatibilization and reprocessing on the isothermal crystallization kinetics of polypropylene/wood flour composites. Polímeros. 2013;23(3):312-319.

15. Silva EA, Moita Neto JM. Possibilidades de melhorias ambientais no processo de reciclagem do polietileno. Polímeros. 2016;26(n.esp):49-54.

16. Santos LS, Silva AHMFT, Pacheco EBAV, Silva ALN. Estudo do efeito da adição de PP reciclado nas propriedades mecânicas e de escoamento de misturas de PP/EPDM. Polímeros. 2013;23(3):389-394.

17. Matei E, Râpă M, Andras ÁA, Predescu AM, Pantilimon C, Pica A, et al. Recycled Polypropylene Improved with Thermoplastic Elastomers. International Journal of Polymer Science. 2017;2017(1):7525923.

18. Wypych G. Handbook of Fillers. Toronto: ChemTec Publishing; 2016.

19. Yu M, Huang R, He C, Wu Q, Zhao X. Hybrid Composites from Wheat Straw, Inorganic Filler, and Recycled Polypropylene: Morphology and Mechanical and Thermal Expansion Performance. International Journal of Polymer Science. 2016;2016(1):2520670.

20. Rjeb M, Labzour A, Rjeb A, Sayouri S, Claire Y, Périchaud A. TG and DSC studies of natural and artificial aging of polypropylene. Physica A: Statistical Mechanics and its Applications. 2005;358(1):212-217.

21. Oliveira RVB, Ferreira CI, Peixoto LJF, Bianchi O, Silva PA, Demori R, et al. Mistura polipropileno/poliestireno: um exemplo da relação processamento-estrutura-propriedade no ensino de polímeros. Polímeros. 2012;23(1):91-96.

22. Canevarolo Jr SV, coord. Técnicas de Caracterização de Polímeros. São Paulo: Artliber; 2003. 
23. Líbano EVDG, Visconte LLY, Pacheco EBAV. Propriedades Térmicas de Compósitos de Polipropileno e Bentonita Organofílica. Polímeros. 2012;22(5):430-435.

24. Agrawal P, Oliveira SI, Araújo EM, Melo TJA. Effect of different polypropylenes and compatibilizers on the rheological, mechanical and morphological properties of nylon 6/PP blends. Journal of Materials Science. 2007;42(13):5007-5012.
25. La Mantia FP. Mechanical properties of recycled polymers. Macromolecular Symposia. 1999;147(1):167-172.

26. McCaffrey Z, Torres L, Flynn S, Cao T, Chiou BS, Klamczynski A, et al. Recycled polypropylene-polyethylene torrefied almond shell biocomposites. Industrial Crops and Products. 2018;125:425-432. 